AGH DRILLING, OIL, GAS • Vol. 33 • No. $1 \cdot 2016$

http://dx.doi.org/10.7494/drill.2016.33.1.135

\author{
Tadeusz Solecki*, Jerzy Stopa*
}

\title{
PETROLEUM SUBSTANCES IN SOIL AND GROUNDWATER IN THE URBAN AREAS**
}

\section{INTRODUCTION}

The study of soil in urban areas is made by sanitary-epidemiological stations and regional environmental inspectorates. According to the reports in the literature [3], in towns topsoil $(0-20 \mathrm{~cm})$ in the allotments has been studied most thoroughly. Most tested indicators are heavy metals such as arsenic, chromium, zinc, lead, copper, nickel. For example, in Warsaw studying of heavy metals in the soil generally has shown contents as below existing standards. According to lead the soil standard is $100 \mathrm{mg} / \mathrm{kg}$ dry matter, however, in several places lead content was in the range $124-282 \mathrm{mg} / \mathrm{kg}$ dry matter, while close to the plant battery was detected a lead content of $120-2123 \mathrm{mg} / \mathrm{kg} \mathrm{DM}$. For cadmium standard for soil is $4 \mathrm{mg} / \mathrm{kg} \mathrm{DM}$, and in soil in allotments were $14.5 \mathrm{mg} / \mathrm{kg} \mathrm{DM}$. The standard for arsenic in soils is $0 \mathrm{mg} / \mathrm{kg}$ DM, and soil samples in the neighbourhood of Electronic Materials Center "Unitra" maximum content of arsenium was $80 \mathrm{mg} / \mathrm{kg} \mathrm{smm}$, and the value of zinc in maintaining standards should not exceed $300 \mathrm{mg} / \mathrm{kg} \mathrm{DM}$, which according to results is observed. On the basis of these results it can be concluded that the overall pollution level of soil in urban areas is not high. This image changes after taking into account other types of pollution. Apart from some heavy metal contamination some urban areas are polluted by petroleum substances from different sources, usually associated with road transport, warehousing and distribution of hydrocarbons. The vast majority of potential sources of contamination are petroleum substances on the surface or just below it, so polluted is mainly aeration layer, and sometimes also the saturation layer.

* AGH University of Science and Technology, Faculty of Drilling, Oil and Gas, Krakow, Poland

** Work performed within the statutory research program of AGH UST 11.11.190.555 


\section{PETROLEUM SUBSTANCES IN SOIL-WATER ENVIRONMENT IN URBAN AREAS}

Sources of waste oil derivatives can be divided into point and linear. Point sources are those that emit pollution to soil and water from a specific location, such as leaking underground fuel tanks, cracked and corroded pipelines, improperly sealed boreholes and injection supplies. Linear sources release pollution into soil and water, for example, the source may be the way along which move damaged vehicles, railroad with leaking tanks or flowing river with contaminants that infiltrate into the ground. Sometimes point or linear sources transform into pollution areas, which are characterized by high surface and volume, e.g. rainwater or groundwater outflow, spreading oil pollution from point or linear sources. In urban areas, pollution by oil products were found where petroleum was stored or handled. This applies to petroleum fuel depots [2], oil filling stations and car transport bases [7], oil refineries [4], industrial [8], etc.

Contamination of oil derivatives have significant impact on soil and water as a toxic effect, mutagenic and carcinogenic, degradation of land and aquifers, inhibition of gas exchange in the vadose zone, restriction the access of light, reduction the oxygen content in the vadose zone. In addition, some petroleum substances, such as gasoline $\left(\mathrm{C}_{6}-\mathrm{C}_{12}\right)$, have a high vapor pressure, which is leading to the displacement of soil air from the vadose zone. The presence of volatile hydrocarbons in the vadose zone is a risk of explosion, especially in urban areas. Risk of explosion may cover a large area of land due to the ease of migration of volatile hydrocarbons in porous unsaturated zone. For this reason, in case of any pollution of soil-water with oil derivatives it is necessary to recognize the source of contamination and the degree of contamination and outline the area of contaminated zone, and then take corrective action.

\section{POLLUTION OF LAND AND WATER AT THE PETROL STATION AND ITS NEIGHBOURHOOD}

For a closer characterization of pollution of soil-water by oil derivatives in urban area, a petrol station in Krakow was chosen, which was operated for decades and is currently excluded from the operation. The area of petrol station is approximately $1080 \mathrm{~m}^{2}$, which represents $2.8 \%$ of the total area of land previously used as a transport base. The station has five underground steel tanks for fuel, and a network of underground fuel pipelines. Pipelines are partially carried in the channels - covered with prefabricated concrete slabs - and partially without channels. Long-term using of petrol station led to a visible oil pollution of the ground surface. In order to assess the condition of soil and water in the petrol station, soil samples from different depths were collected, by drilling 29 exploratory wells by mechanical system without using of drilling mud, following the rules for drilling test holes for soil sampling according to norm ISO 10381 - Soil quality - sampling. Soil samples were collected in accordance with the decision of the administrative authority approving the project of geological work. 


\subsection{Analysis of the results of soil quality laboratory tests}

Soil samples were tested for petroleum hydrocarbon content with separation for aliphatic hydrocarbons, gasoline with the number carbons of 6-12, mineral oils with the number of carbons 12-35 and aromatic hydrocarbons. Due to the limited format of the paper tabular format of results is not presented.

To approximate the characteristics of the general population described by matrix containing the results of five test indicators in each of 90 soil samples, the selected statistical parameters are summarized in Table 1. Test indicators include: aliphatic hydrocarbons, aromatic hydrocarbons, gasoline $\left(\mathrm{C}_{6}-\mathrm{C}_{12}\right)$, mineral oil $\left(\mathrm{C}_{12}-\mathrm{C}_{35}\right)$ and total hydrocarbons. Table 1 contains information of: the number of measurements, the minimum content of the test indicator, the maximum level of the test indicator, the number of samples with known exceeding standards, the place of samples with known exceeding standards, the arithmetic mean $\mathrm{X}_{\mathrm{av}}$, standard deviation $\sigma$ and median $\mathrm{M}_{\mathrm{e}}$.

Table 1

Summary of statistical parameters - hydrocarbons in the soil

\begin{tabular}{|c|c|c|c|c|c|}
\hline \multirow[b]{2}{*}{ Statistical parameter } & \multicolumn{4}{|c|}{ Petroleum hydrocarbons in soil } & \multirow{2}{*}{$\begin{array}{c}\text { Sum of } \\
\text { hydrocarbon }\end{array}$} \\
\hline & Alifathic & Aromatic & $\begin{array}{c}\text { Gasoline } \\
\mathrm{C}_{6}-\mathrm{C}_{12}\end{array}$ & $\begin{array}{c}\text { Mineral oil } \\
\mathrm{C}_{12}-\mathrm{C}_{35}\end{array}$ & \\
\hline No. of samples & 90 & 90 & 90 & 90 & 90 \\
\hline Content & \multirow{2}{*}{27.964} & \multirow{2}{*}{0.011} & \multirow{2}{*}{0.033} & \multirow{2}{*}{27.942} & \multirow{2}{*}{27.975} \\
\hline Min [ppm] & & & & & \\
\hline Content & \multirow{2}{*}{11806.5} & \multirow{2}{*}{628.7} & \multirow{2}{*}{1886.1} & \multirow{2}{*}{10549.1} & \multirow{2}{*}{12435.2} \\
\hline Max [ppm] & & & & & \\
\hline Max/Min & 422.20 & 57154.5 & 57154.5 & 377.54 & 444.51 \\
\hline $\begin{array}{l}\text { Number of exceeding } \\
\text { standards }\end{array}$ & $\begin{array}{c}\text { lack } \\
\text { of standard }\end{array}$ & 87 & 83 & 79 & $\begin{array}{c}\text { lack } \\
\text { of standard }\end{array}$ \\
\hline Max fold excess & $\begin{array}{c}\text { lack } \\
\text { of standard }\end{array}$ & 804.5 & 377.22 & 52.7455 & $\begin{array}{c}\text { lack } \\
\text { of standard }\end{array}$ \\
\hline- no. of well & - & M-2 & M-1 & M-1 & - \\
\hline - depth: & - & 0.3 & 2 & 2 & - \\
\hline Mean $X_{\mathrm{av}}[\mathrm{ppm}]$ & 910.13 & 42.04 & 126.12 & 826.05 & 952.17 \\
\hline $\begin{array}{l}\text { Standard deviation } \\
\sigma[\mathrm{ppm}]\end{array}$ & 1704.03 & 94.43 & 283.29 & 1527.67 & 1793.16 \\
\hline Median $\mathrm{M}_{\mathrm{e}}[\mathrm{ppm}]$ & 500.42 & 15.26 & 45.78 & 478.29 & 515.10 \\
\hline Max fold excess & $\begin{array}{c}\text { lack } \\
\text { of standard }\end{array}$ & 804.5 & 377.22 & 52.7455 & $\begin{array}{c}\text { lack } \\
\text { of standard }\end{array}$ \\
\hline- no. of well & - & M-2 & M-1 & M-1 & - \\
\hline - depth: & - & 0.3 & 2 & 2 & - \\
\hline
\end{tabular}


Soil quality standards for hydrocarbons are established in the regulation of Ministry of Environment for soil quality standards [11]. Pursuant to the requirements of this Regulation the comparative analysis was made, in which standards for sozological-urban areas of group B were adopted, because of the function which plays and will play the area of research. All the tested samples characterized by the ratio of the soil filtration greater than $1 \times(10-7) \mathrm{m} / \mathrm{s}$.

Totally, 90 samples of soil were taken, from which the value limits were exceeded in 79 samples (mineral oil), 83 samples (gasoline) and 87 samples (aromatic hydrocarbons). The largest spread in the results was in the samples with exceeded limits for gasoline and aromatic hydrocarbons.

Summary characterized graphically range studies include Figures 1 and 2, which shows the location of sampling points and times exceeded permissible content of gasoline $\left(\mathrm{C}_{6}-\mathrm{C}_{12}\right)$ and mineral oil $\left(\mathrm{C}_{12}-\mathrm{C}_{35}\right)$. Times the overruns are expressed as the ratio measured in the content of different types of hydrocarbons allowed for their content. A vertical line drawn by the numerical value of 1 , a qualitative boundary separation between samples. All samples, which are located on the left side of the border, does not exceed the required standards, and the sample contained no right complying to the standards. The comparative study shows that $97 \%$ had exceeded standards for gasoline and $88 \%$ of mineral oil. Maximum times the overruns were recorded in monitoring well M-1 (for gasoline and mineral oil at a depth of $2 \mathrm{~m}$ ).

At the petrol station research boreholes E-1, E-2, and monitoring wells M-1 to M-6, M-7 and M-19 were located. Figure 3 shows the map generated in Surfer, representing the maximum times of exceeding standards according to any oil pollution indicator shown in Figures 1 and 2. The map in Figure 3 shows, that in accordance with the provisions of the Law on the Prevention and Remedying Environmental Damage [12], at the area covered by the map should be carried out actions which make soil quality lower than maximum standards.

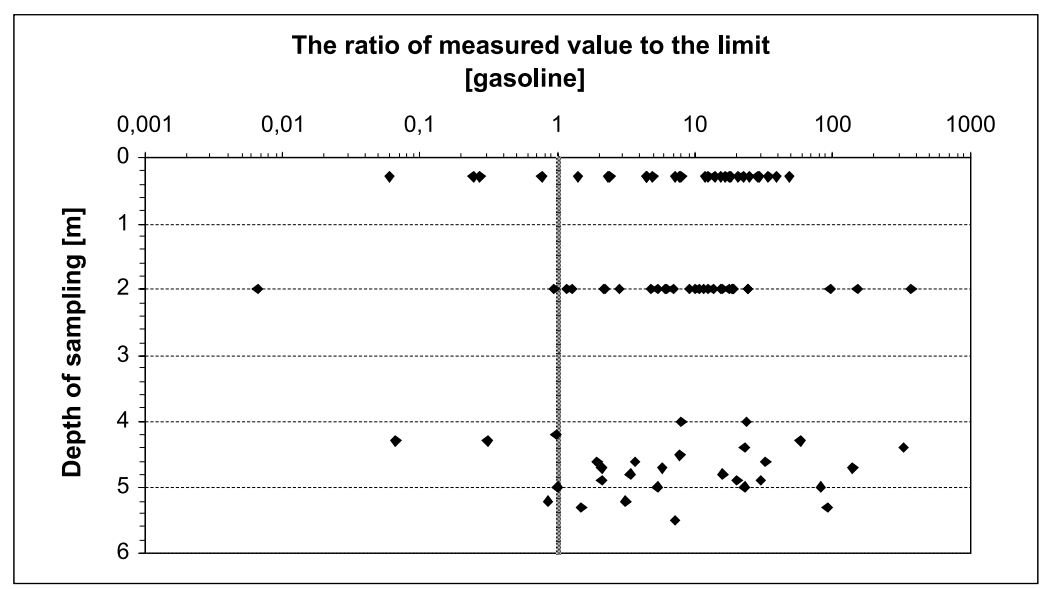

Fig. 1. Quality of the soil in relation to the amount of gasoline - exceeding standard when $\mathrm{C}_{\text {arom }} / \mathrm{C}_{\mathrm{dop}}>1$ 


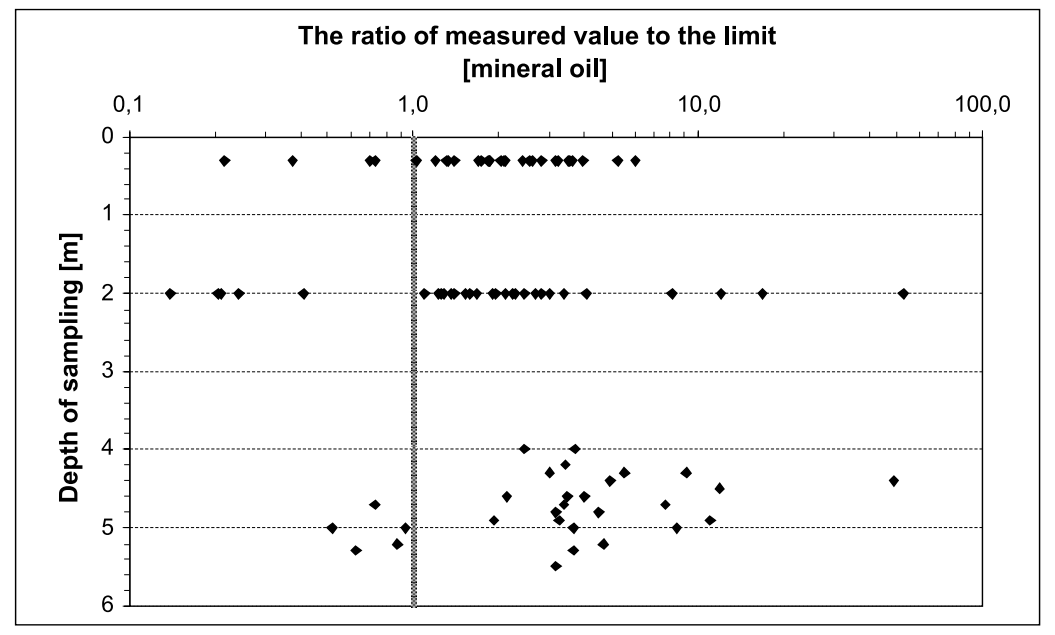

Fig. 2. Quality of the soil in relation to the amount of mineral oil - exceeding standard when $\mathrm{C}_{\text {arom }} / \mathrm{C}_{\mathrm{dop}}>1$

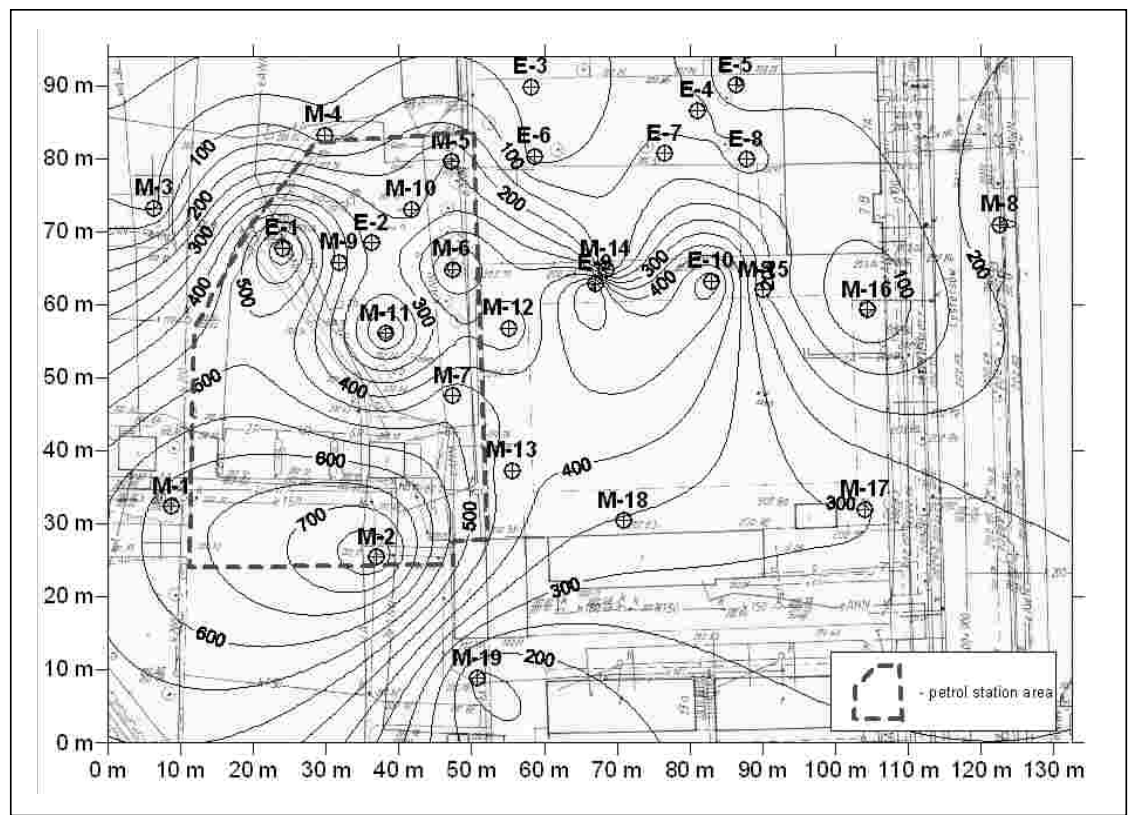

Fig. 3. Exceeding of quality standards of the soil and ground at the oil filling station and its neighbourhood

As can be seen from the map in Figure 3, biggest exceeding of soil quality standards is not only at the petrol station, but also the neighboring areas, where was a significant excess of standards which require corrective action. 


\subsection{Analysis of the results of laboratory tests of underground water}

The selected boreholes have been converted into monitoring wells, and their design has enabled collection of representative samples of groundwater in accordance with the general requirements [5]. As a result of field research of the film thickness, layer of petroleum products floating on the groundwater was found in some monitoring wells. From the monitoring wells, where was not a floating layer of liquid petroleum product, water samples for laboratory analysis were collected. Results of water quality in monitoring wells are shown in Table 2.

Table 2

The results of field and laboratory studies of underground water samples

\begin{tabular}{|c|c|c|c|c|}
\hline \multirow[b]{2}{*}{ No. of well } & \multicolumn{2}{|c|}{ Fieldworks results } & \multicolumn{2}{|c|}{ Laboratory test results } \\
\hline & $\begin{array}{c}\text { Groundwater } \\
\text { table } \\
{[\mathrm{m}]}\end{array}$ & $\begin{array}{c}\text { Petroleum product } \\
\text { at water table } \\
{[\mathrm{cm}]}\end{array}$ & $\begin{array}{c}\mathrm{TPH} \\
{[\mathrm{mg} / \mathrm{l}]}\end{array}$ & $\begin{array}{c}\text { Groundwater } \\
\text { quality class }\end{array}$ \\
\hline M-1 & 3.56 & 0.6 & - & $\mathrm{V}$ \\
\hline M-2 & 3.30 & 0.0 & 0.141 & II \\
\hline M-3 & 3.07 & 0.0 & 0.186 & II \\
\hline M-4 & 3.70 & 0.0 & 0.308 & III \\
\hline M-5 & 3.62 & 0.0 & 0.271 & II \\
\hline M-6 & 3.19 & 80 & - & $\mathrm{V}$ \\
\hline M-7 & 3.36 & 40 & - & $\mathrm{V}$ \\
\hline M-8 & 2.80 & 0.0 & 0.523 & III \\
\hline M-9 & 3.28 & $>100$ & - & $\mathrm{V}$ \\
\hline M-10 & 3.36 & 0.0 & 0.313 & III \\
\hline M-11 & 3.26 & $>100$ & - & V \\
\hline M-12 & 2.98 & $>100$ & - & $\mathrm{V}$ \\
\hline M-13 & 3.27 & 0.0 & 1.347 & II \\
\hline M-14 & 3.26 & $>100$ & - & $\mathrm{V}$ \\
\hline M-15 & 3.24 & $>100$ & - & $\mathrm{V}$ \\
\hline M-16 & 3.66 & 0.0 & 0.304 & III \\
\hline M-17 & 3.51 & 0.0 & 0.022 & I \\
\hline M-18 & 3.31 & 0.0 & 0.514 & III \\
\hline M-19 & 3.39 & 0.0 & 0.24 & II \\
\hline P-1 & 3.60 & 0.0 & 0.067 & I \\
\hline
\end{tabular}


Regulation of the Ministry of Environment from 23 July 2008 on the criteria and methods of evaluation of groundwater [13] introduces the classification for the presentation of groundwater covering five classes of water quality. As shown in Table 2, at studying area conducted with water quality monitoring in 20 wells, were 2 samples of water in Class I (very good quality), 5 samples of Class II water quality, four samples of Class III water (satisfactory quality), and 8 water samples from class V (poor quality). For Class V, the presence of hydrocarbon floating on the groundwater table confirms the significant impact of human activities.

Based on the results of groundwater quality in the individual wells contour covering the area with a layer of floating oil-derived substances in the water table was created in computer program Surfer. This contour is shown at the map in Figure 4.

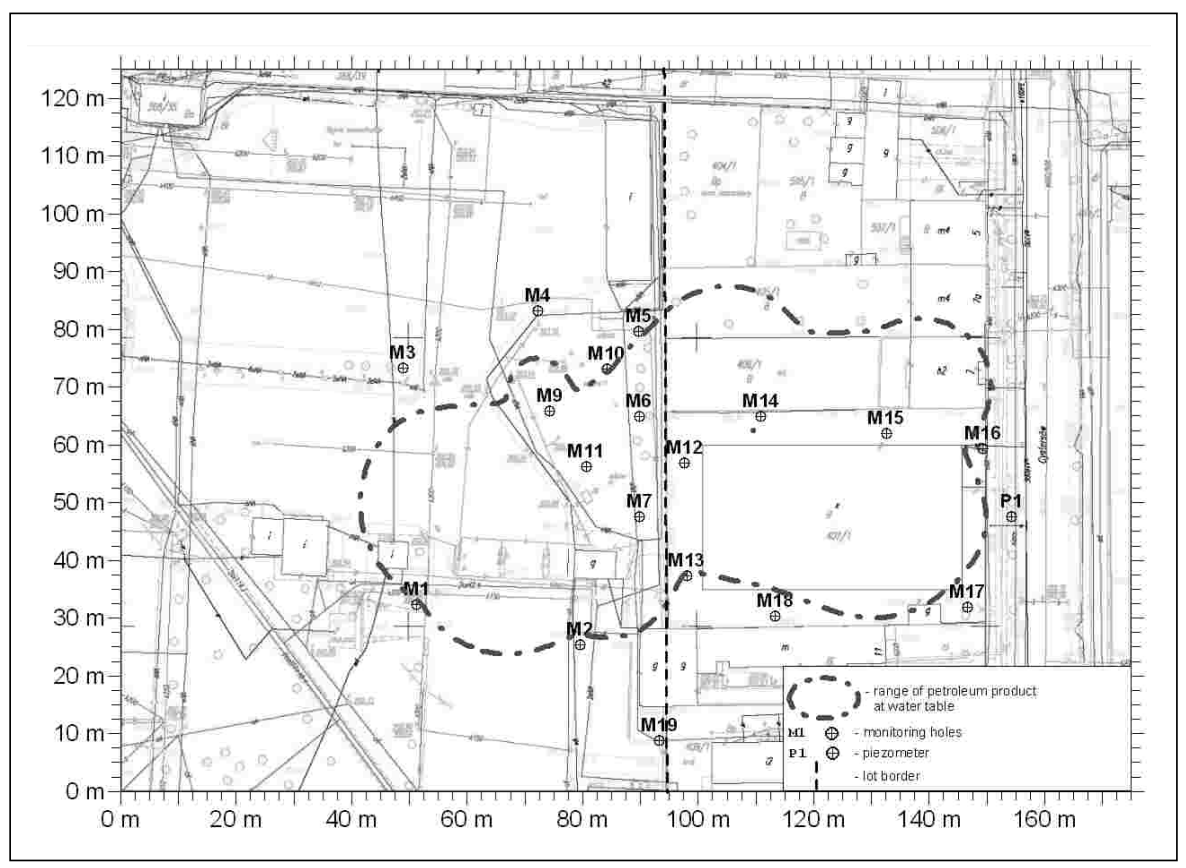

Fig. 4. Contour of floating hydrocarbon layer on underground water table

Monitoring wells M-1 to M-6, M-7 and M-19 are located on lot on which petrol station objects are located. Other monitoring wells are located on lots of other owners. As can be seen from the outline of the position of the floating layer of oil product on the groundwater table, contamination with petroleum substances spread from the area of petrol station on adjacent plots. Table 2 shows that the culmination of pollution moved from the petrol station, and is located in the neighbourhood of wells M-9, M-11, M-12, M-14 and M-15. 


\section{ANALYSIS OF ENVIRONMENTAL AND SAFETY RISKS}

Due to the flow of oil products from the place of leak to the neighboring lots, the problem of the risks arising from the presence of petroleum in soil-water environment should be seen at the background of geological, hydro-geological and hydrographic conditions, and the course of underground infrastructure.

Petrol station is located within a large geological unit - Carpathian Foredeep. It is built with thick tertiary clays and shales with interbeds of fine sand and gypsum. The area of it is eroded by the Vistula River and its tributaries. Top of Miocene clays in the analyzed area lies at the depth of $12.0 \mathrm{~m}$ below ground level. Above Tertiary lies Quaternary - Pleistocene, forming accumulation terraces of the Vistula river. The drill holes analyzed that under the soil layer with a thickness of $0.2 \mathrm{~m}$ or embankments with thickness of $0.5-2.2 \mathrm{~m}$ lies silt loam layer with a thickness of $0.6-2.0 \mathrm{~m}$ (with lenses of silty sands), beneath thick layer of peat $0,3-0.8 \mathrm{~m}$, which is directly behind the dust layer with a thickness of $0,1-0,5$, which is unpermeable or poorly-permeable and lies on the permeable sand and gravel, drilled at a depth of 4.3-5.3 m below ground level.

Groundwater in the area of petrol stations occur only within the Quaternary as a single aquifer associated with sand and gravel. Underground water table, which is under pressure due to lying above silts and peats, was drilled at depths of $4.3-5.3 \mathrm{~m}$ below the ground, and stabilized at depths of 2.8 to $3.7 \mathrm{~m}$ below. Aquifer permeability coefficient is $3 \times(10-4) \mathrm{m} / \mathrm{s}$ [7]. Water of this level in the past has been used for drinking and domestic purposes, as evidenced by numerous wells in the area near petrol station. At the station's lot were three wells with a depth of $15.0 \mathrm{~m}$. Nowadays, the wells are removed and the supply is from the urban water supply. Also, on the property located adjacent to the east, was a household dug well, which was closed due to water pollution by oil derivatives and explosion hazard. This well was located in the area of hydrocarbon floating on the underground water table, approximately $35 \mathrm{~m}$ from the border of petrol station lot. The culmination of contamination has moved from the area of the petrol stations to the east, at the adjacent plots. This is due to the fact that the natural movement of groundwater is carried out in an easterly direction, towards the river Białucha, which is the left-hand tributary of the Vistula River. Białucha flows at a distance of about $450 \mathrm{~m}$ from petrol station and drains underground water from the analyzed area, causing the spread of contamination. The dynamics of underground water drainage in the area is affected by the damming of the Vistula River water level "Dąbie" and natural variation of water level in the river Vistula, which causes fluctuations in the underground water level in the petrol station up to $1.0 \mathrm{~m}$.

In addition to the risk of spread of oil products to the underground water table, there is a real risk of the possibility of oil products penetration to the sewer system located in the street. In the area of geological works underground water table stabilized at a depth 3,25-3,74 m below ground level, and in relation to sea level elevation of the water table contained within the 199.39 to $199.51 \mathrm{~m}$ above sea level. Elevation of the bottom of the street sewer pit a few meters away from the contour of the water table floating on 
the groundwater petroleum substances is 199.56 meters above sea level. This creates a real risk for hydrocarbon seepage drains. Contamination of hydrocarbon in sewer system is a danger for the people - their health (toxic fumes, hydrocarbons) and life (potentially explosive hydrocarbon vapors).

In summary it can be stated that at the research area the environmental damage occurred, as art. 6 section 11 of the Act of 13 April 2007 on the prevention of environmental damage and its repair [12] defines environmental damage as a negative, measurable change in the status or function of the natural sciences, assessed in relation to the initial state, which is caused directly or indirectly by the activities carried out by the user of the environment. Damage can occur in water, having a significant negative impact on the ecological, chemical and quantitative water condition, or in the ground, including in particular the pollution that may endanger the health of people. In accordance with Art. 9 paragraph. 2 point. 2 of the Act [12], in case of environmental damage, the user of the environment is required to take corrective action.

Due to the necessarity to carry out remedial actions, removal of petroleum substances out of the ground and groundwater has been made. The project provides two phases of hydrocarbon pollution abatement technology: the hydrodynamic phase (liquid hydrocarbon removal from water surface by vertical drainage wells and supporting wells) and microbiological phase (hydrocarbon removal from soil and groundwater) [9]. The main difficulty occurred due to the hydrogeological conditions found in underground water table (under pressure), on which flows a layer of petroleum substances. Such case has not been described in the leading positions of the literature $[1,6]$. This problem was solved by organizing several technologies and optimization procedures described in [10]. The end of recultivation works is planned to 2016.

\section{CONCLUSIONS}

1. Some urban areas are contaminated with petroleum substances from various sources, such as bases of liquid fuels, petrol stations, transport bases, oil refineries and other industrial plants using fuel.

2. According to the research, soil at petrol stations and their surroundings does not keep standards for permissible levels of oil products that are exceeded several hundred times.

3. At the area of petrol station, groundwater due to oil derivatives contamination is classified as poor quality, and the presence of hydrocarbon floating on the groundwater table confirms the significant impact of human activities.

4. Case study led to the conclusion that a deep foundation of underground fuel tanks may violate the natural isolation of aquifers and petroleum substances leaking from tanks can contaminate underground water and spread in a impermeable layer.

5. Migration of hydrocarbon liquid from leaking installation into the aquifer system with a table under pressure is an unusual case, which creates significant problems of design and realization of the environmental damage repair. 


\section{REFERENCES}

[1] Boulding J.R., Ginn J.S.: Practical Handbook of Assesment, Prevention and Remediation. Lewis Publishers. A CRC Press Company, Boca Raton, London, New York, Washington, D.C, 2004.

[2] Fąfara Z., Solecki T.: Badania porównawcze koncentracji węglowodorów $w$ gruncie na terenie bazy paliw naftowych. Wiertnictwo, Nafta, Gaz, No. 23/1, 2006, pp. 199-206.

[3] Kowalik P.: Ochrona środowiska glebowego. Wydawnictwo Naukowe PWN, Warszawa 2012.

[4] Macuda J., Solecki T.: Zanieczyszczenie wód podziemnych substancjami węlowodorowymi w rejonie rafinerii ropy naftowej. Wiertnictwo, Nafta, Gaz, No 23/1, 2006, pp. 313-318.

[5] Nielsen D.M.: Practical Handbook of Environmental Site Characterization and Ground-Water Monitoring. CRC, Taylor \& Francis, Boca Raton, 2005.

[6] Sharma H.D., Reddy K.R.: Geoenvironmental Engineering. Site Remediation Waste Containment and Emerging Waste Management Technologies. John Wiley \& Sons Inc., Hoboken, New Jersey, 2004.

[7] Solecki T.: Dokumentacja geologiczna określająca warunki hydrogeologiczne i stan środowiska gruntowo-wodnego $w$ zwiąku z istniejącym obiektem przy ul. Cystersów w Krakowie, mogacym zanieczyścić wody podziemne. Archiwum Geologiczne Urzędu Marszałkowskiego w Krakowie (unpublished), 2005.

[8] Solecki T.: Analiza zagrożeń jakości wód leczniczych ze złoża „,Mateczny” w związku z zanieczyszczeniem węlowodorami powierzchni ziemi na terenie zlikwidowanych zakładów chemicznych. Wiertnictwo, Nafta, Gaz, vol. 27, No.1-2, 2010, pp. 381-390.

[9] Solecki T., Stopa J. et al.: Projekt działań naprawczych $w$ powierzchni ziemi zanieczyszczonej produktami naftowymi na terenie po byłej stacji paliw naftowych $w$ Krakowie, ul. Cystersów. Archiwum Regionalnej Dyrekcji Ochrony Środowiska w Krakowie (unpublished), 2011.

[10] Stopa J., Solecki T.: Optimization of the pump-and treat system for remediation of an aquifer polluted by mineral oil. Charles University, Faculty of Science, Prague 2004.

[11] Rozporządzenie Ministra Środowiska z dnia 9 września 2002 r. w sprawie standardów jakości gleby oraz standardów jakości ziemi. Dz.U. 2002 nr 165 poz. 1359.

[12] Ustawa z dnia 13 kwietnia 2007 r. o zapobieganiu szkodom $w$ środowisku i ich naprawie. Dz.U. 2007 nr 75 poz. 493.

[13] Rozporządzenie Ministra Środowiska z dnia 23 lipca 2008 r. w sprawie kryteriów i sposobu oceny stanu wód podziemnych. Dz.U. 2008 nr 143 poz. 896. 